Evans, A. E., Farber, S., Brunet, S., and Mariano, P. J. (1963). Cancer, 16, 1302 .

Frei, E., et al. (1965). Blood, 26, 642

Haggard, M. E., Fernbach, D. J., Holcom's, T. M., Sutow, W. W., Victti, T. J., and Windmiller, J. (1968). Cancer, 22, 438 .

Hananian, J., Holland, J. F., and Sheehe, P. (1965). Proceedings of the American Association of Cancer Research, 6, 26.

Henderson, E. S. (1967). Cancer Research, 27, 2570.

Heyn, R., Beatty, E. C., Hammond, D., Louis, J., Pierce, M., Murphy, M. L., and Severo, N. (1965). Proceedings of the American Association of Cancer Research, 6, 27.
Howard, J. P. (1967). Cancer Chemotherapy Reports, 51, 465.

Karon, M. R. (1968). Cancer Chemotherapy Reports, 52, 473.

Karon, M. R., Freireich, E. J., and Frei, E. (1962). Pediatrics, 30,

Karon, M. R., et al. (1966). Clinical Pharmacology and Therapeutics, 7, 332. Krivit, W., Brubaker, C., Hartmann, J., Murphy, M. L., Pierce, M., and
Thatcher, G. (1966). Fournal of Pediatrics, 68, 965.

Krivit, W., Brubaker, C., Thatcher, L. G., Pierce, M., Perrin, E., and Hartmann, J. R. (1968). Cancer, 21, 352

Mathé, G., et al. (1967). Lancet, 2, 380.

\title{
Type III Hyperlipoproteinaemia
}

\author{
PETER BORRIE,* M.D., F.R.C.P.
}

British Medical fournal, 1969, 2, 665-667

\begin{abstract}
Cummary : Eighteen patients with type III hyperlipoproteinaemia, diagnosed on the basis of skin lesions, serum lipids, and lipoprotein electrophoresis, have been fully investigated over a period of 15 years. The incidence of coronary artery disease was only slightly increased, and was not increased at all among first-degree relatives. Peripheral occlusive arterial disease was probably more common. An increased incidence of carbohydrate intelerance was found in neither the patients nor their relatives. The effects of treatment on the skin were uniformly good.
\end{abstract}

\section{Introduction}

The clinical features of the various types of xanthomatosis have remained curiously ill-defined over the years. This is partly because the syndrome has presented in and been studied by a number of separate disciplines. Dermatological, cardiac, and metabolic departments have independently studied their own group of patients. Possibly more important than this, however, has been the undue emphasis given to the biochemical and genetic features of the condition, so that it has become little more than a series of lipid levels, a lipoprotein electrophoretic pattern, or a family tree. For instance, Fredrickson et al. (1967) studied the plasma lipids and electrophoretic pattern in 24 cases of type III hyperlipoproteinaemia, but described the individual clinical features in only eight (Fredrickson and Lees, 1966). Even so, this remains the largest series to date.

The present paper describes the clinical and biochemical features in 18 cases of type III hyperlipoproteinaemia observed over a number of years. Cases 1,11 , and 13 were reported in a previous communication (Cases 4, 6, and 5 respectively in Borrie, 1957) as being examples of idiopathic hypercholesterolaemic xanthomatosis associated with triglyceridaemia.

\section{Clinical Features}

The clinical features are summarized in Table I. There were 14 men and 4 women, the ages at onset varying from 24 to 53 . All were referred to hospital on account of their skin lesions, which in every case were the first manifestations of their disease. During the same period of time only eight other cases of primary hyperlipoproteinaemia were seen in the skin depart-

* Physician, Department of Dermatology, St. Bartholomew's Hospital, London E.C.1. ment. The duration of the disease to date varies from 1 to 30 years, four patients having suffered for less than five years, two for from 5 to 10 years, nine from 11 to 20 years, and three for more than 20 years.

\begin{tabular}{|c|c|c|c|c|c|c|c|c|c|c|}
\hline \multirow{2}{*}{$\begin{array}{l}\text { Case } \\
\text { No. }\end{array}$} & \multirow{2}{*}{ Sex } & \multirow{2}{*}{$\begin{array}{c}\text { Age } \\
\text { at } \\
\text { Onset }\end{array}$} & \multirow{2}{*}{$\begin{array}{c}\text { Dura- } \\
\text { tion } \\
\text { (Years) } \\
\text { in } \\
1968\end{array}$} & \multicolumn{4}{|c|}{ Xanthomata } & \multirow{2}{*}{ Arcus } & \multirow{2}{*}{$\begin{array}{l}\text { Dia- } \\
\text { betes }\end{array}$} & \multirow{2}{*}{$\begin{array}{c}\text { Cardio- } \\
\text { vascular } \\
\text { Involvement }\end{array}$} \\
\hline & & & & $\mathrm{E}$ & $\mathbf{P}$ & $\mathrm{T}$ & $\mathrm{TN}$ & & & \\
\hline 1 & $M$ & 40 & 20 & + & + & + & - & + & - & $\begin{array}{l}\text { Cardiac and peri- } \\
\text { pheral arierial }\end{array}$ \\
\hline $\begin{array}{l}2 \\
3\end{array}$ & $\mathrm{~F}$ & 34 & 30 & + & + & + & + & - & - & $\begin{array}{l}\text { pneral arierial } \\
\text { Cardiac }\end{array}$ \\
\hline $\begin{array}{l}3 \\
4\end{array}$ & $\stackrel{F}{M}$ & $\begin{array}{l}53 \\
28\end{array}$ & $\begin{array}{l}1 \\
2\end{array}$ & \pm & $\begin{array}{l}+ \\
+\end{array}$ & $\begin{array}{l}+ \\
+\end{array}$ & - & - & - & - \\
\hline 5 & $M$ & 28 & 19 & - & - & + & - & - & $\overline{-}$ & E \\
\hline 6 & $M$ & 30 & 30 & - & + & + & + & + & + & (E.C.G. not per- \\
\hline 7 & $M$ & 38 & 4 & - & + & + & - & - & - & d) \\
\hline $\begin{array}{l}8 \\
9\end{array}$ & & 2 & 16 & $\overline{-}$ & $\overline{-}$ & + & - & - & - & - \\
\hline 10 & $M$ & 26 & $\begin{array}{l}18 \\
14\end{array}$ & $\bar{t}$ & t & $\begin{array}{lll}+ \\
+\end{array}$ & $\bar{t}$ & $\overline{-}$ & $z$ & - \\
\hline 11 & $M$ & 28 & 21 & + & + & + & - & - & $\overline{-}$ & - \\
\hline & $M$ & 29 & 9 & - & - & + & - & - & - & $\begin{array}{l}\text { Rheumatic heart } \\
\text { disease. }\end{array}$ \\
\hline 13 & $M$ & 41 & 18 & - & + & + & - & - & - & $\begin{array}{l}\text { Peripheral arterial } \\
\text { Cardiac }\end{array}$ \\
\hline 14 & $\mathrm{~F}$ & 5 & 14 & - & + & + & - & - & - & Cardiac \\
\hline 15 & $F$ & 48 & 13 & - & + & + & - & - & - & (E.C.G. not \\
\hline 16 & $M$ & 37 & 12 & - & - & + & - & - & + & performed) \\
\hline $\begin{array}{l}17 \\
18\end{array}$ & $M$ & 37 & 8 & - & + & + & - & - & - & Cardiac \\
\hline & $\mathbf{M}$ & 24 & 4 & - & + & + & & - & - & 一 \\
\hline
\end{tabular}

All types of xanthomata were found, eruptive xanthomata occurring in five patients, plane xanthomata of the palmar aspect of the fingers or hands in 13, and tuberose xanthomat in all. These latter, as well as affecting the more usual sites of the elbows, knees, and buttocks, also involved the fingers and hands in nine cases. The frequent involvement of the fingers and hands was one of the most characteristic features of the series, and the types of lesions are illustrated in Fig. 1. Only three patients had tendon lesions and one (Case 1) had xanthelasma. One patient had a corneal arcus before the age of 45 . One patient (Case 10) had gout, beginning at the age of 39,13 years after the onset of the hyperlipoproteinaemia.

One patient had diabetes mellitus beginning at the age of 46 , nine years after the onset of the hyperlipoproteinaemia. The glucose tolerance test was performed in 13 other cases (see Table IV), in all of which it was normal.

Six patients had cardiovascular disease, and the details are shown in Table II. Case 12 also had rheumatic heart disease at the age of 14 and a successful mitral valvotomy at the age of 27 , but this was not thought to be associated with the hyper- 
lipoproteinaemia. He subsequently had a successful bypass operation performed in 1967 to relieve the peripheral arterial obstruction. At the time of writing all the patients were alive and leading normal lives with the exception of one (Case 14), who died of increasingly severe congestive heart failure at the age of 62 , following a coronary thrombosis at the age of 58 .

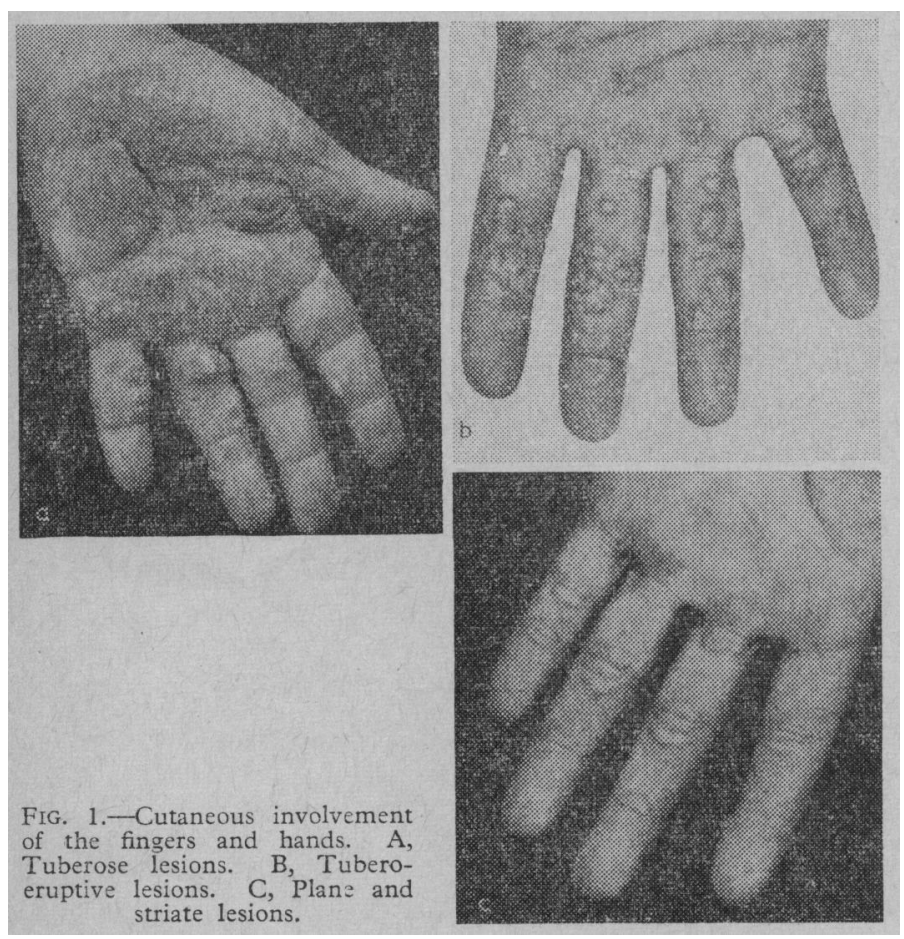

\begin{tabular}{|c|c|c|c|c|c|}
\hline $\begin{array}{l}\text { Case } \\
\text { No. }\end{array}$ & $\begin{array}{c}\text { Duration } \\
\text { of Disease } \\
\text { before } \\
\text { Cardio- } \\
\text { vascular } \\
\text { Involvement } \\
\text { (Years) }\end{array}$ & $\begin{array}{r}\text { Cholesterol } \\
\text { (At Time of C } \\
\text { Les } \\
\text { (mg./ }\end{array}$ & $\begin{array}{l}\text { Triglyceride } \\
\text { ardiovascular } \\
\text { ion) } \\
50 \mathrm{ml} . \text { ) }\end{array}$ & $\begin{array}{c}\text { Age at } \\
\text { Cardio- } \\
\text { vascular } \\
\text { Involve- } \\
\text { ment }\end{array}$ & $\begin{array}{l}\text { Type of } \\
\text { Cardiovascular } \\
\text { Lesion }\end{array}$ \\
\hline 1 & 27 & 388 & 600 & 58 & $\begin{array}{l}\text { Old anterior infarct } \\
\text { found on E.C.G. } \\
\text { Right femoral block }\end{array}$ \\
\hline 2 & 20 & 889 & 816 & 52 & $\begin{array}{l}\text { Angina. Normal } \\
\text { E.C.G. }\end{array}$ \\
\hline $\begin{array}{l}12 \\
13\end{array}$ & $\begin{array}{r}6 \\
16\end{array}$ & $\begin{array}{l}378 \\
374\end{array}$ & $\begin{array}{l}388 \\
720\end{array}$ & $\begin{array}{l}36 \\
57\end{array}$ & $\begin{array}{l}\text { Left iliac block } \\
\text { Angina and coronary } \\
\text { thrombosis }\end{array}$ \\
\hline 14 & 5 & 530 & Turbid & 58 & $\begin{array}{l}\text { Angina and coronary } \\
\text { thrombosis. Died } \\
\text { aged } 62 \text { of conges- } \\
\text { tive heart failure }\end{array}$ \\
\hline 17 & 7 & 427 & 580 & 44 & $\begin{array}{l}\text { Symptomless left ven- } \\
\text { tricular ischaemia } \\
\text { found on E.C.G. }\end{array}$ \\
\hline
\end{tabular}

The family histories are shown in Table III. The minimal history of cardiovascular disease in first-degree relatives is evident. Cases 16 and 17 are brothers, and thus the family incidence of both diabetes and hyperlipoproteinaemia is also probably not more than might be expected among first-degree relatives. One patient had a father with gout, and this patient was the only one in the series who suffered from gout, in spite of the generally high serum uric acid values (Table IV).

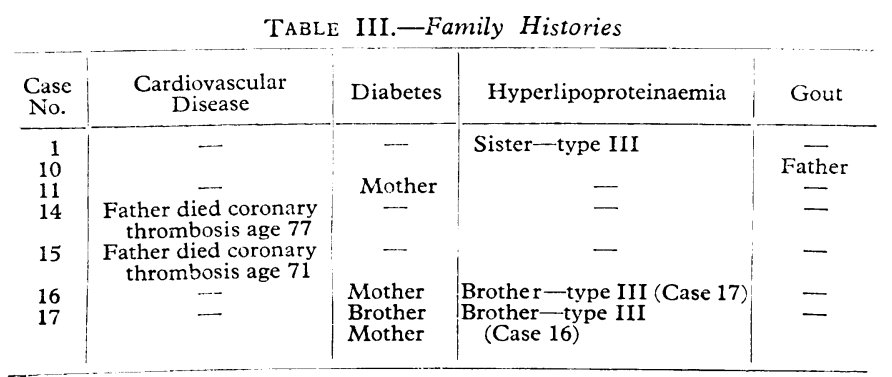

\section{Biochemical Features}

The biochemical findings are given in Table IV. The triglycerides were estimated after an overnight fast and the cholesterol values in column 2 are those found in the same sample of blood. These estimations were all done in 1968 and at least one month after discontinuing all cholesterol-lowering agents. However, many of the patients had lost 1 to 3 st. $(6 \cdot 4-19 \mathrm{~kg}$.) in weight as a result of dieting, and the lipid levels shown are lower than those at the onset of the disease. In these cases the cholesterol level when the patient was first seen is given in parenthesis in column 2. The triglyceride levels had not been previously recorded. The cholesterol levels were raised in all cases and the triglycerides in all in which it was estimated. In those cases in which the triglycerides were not estimated the serum was constantly turbid. The nean serum uric acid level in 12 patients was $7.33 \mathrm{mg} . / 100 \mathrm{ml}$., with a standard deviation of 1.67 . In six of these the level exceecicd $8 \mathrm{mg} . / 100 \mathrm{ml}$., but only one (Case 10) suffered from gout-the patient who gave a family history of gout. (Table III). The glucose tolerance test was performed in 14 cases, being normal in 13 and diabetic in one. None of the remaining patients had glycosuria.

TABLE IV.-Biochemical Features

\begin{tabular}{|c|c|c|c|c|c|}
\hline $\begin{array}{l}\text { Case } \\
\text { No. }\end{array}$ & $\begin{array}{l}\text { Cholesterol } \\
\text { (mg./100 ml.) }\end{array}$ & $\begin{array}{l}\text { Triglyceride } \\
\text { (mg./100 ml.) }\end{array}$ & $\begin{array}{l}\text { Electro- } \\
\text { phoresis }\end{array}$ & $\begin{array}{c}\text { Uric Acid } \\
\text { (mg./100 ml.) }\end{array}$ & $\begin{array}{c}\text { Glucose } \\
\text { Tolerance Test }\end{array}$ \\
\hline $\begin{array}{r}1 \\
2 \\
3 \\
4 \\
5 \\
6 \\
7 \\
8 \\
9 \\
10 \\
11 \\
12 \\
13 \\
14 \\
15 \\
16 \\
17 \\
18\end{array}$ & $\begin{array}{l}388(700) \\
889 \\
455 \\
404(1,096) \\
235(380) \\
840 \\
486 \\
455 \\
430 \\
480(780) \\
310(650) \\
378 \\
374(470) \\
960 \\
508 \\
470 \\
430(700) \\
410\end{array}$ & $\begin{array}{c}600 \\
816 \\
750 \\
449 \\
420 \\
\text { Turbid } \\
450 \\
520 \\
509 \\
980 \\
420 \\
388 \\
720 \\
\text { Turbid } \\
\text { Turbid } \\
\text { Turbid } \\
740 \\
650\end{array}$ & $\begin{array}{l}+ \\
+ \\
+ \\
+ \\
+ \\
+ \\
+ \\
+ \\
+ \\
+ \\
+ \\
+ \\
+ \\
+ \\
- \\
+ \\
+ \\
-\end{array}$ & $\begin{array}{l}\frac{9 \cdot 0}{5 \cdot 0} \\
\frac{6 \cdot 2}{6 \cdot 2} \\
8 \cdot 6 \\
6 \cdot 5 \\
8 \cdot 7 \\
8 \cdot 4 \\
6 \cdot 1 \\
9 \cdot 3 \\
\frac{6 \cdot 6}{4 \cdot 6} \\
\frac{-6 \cdot 9}{-}\end{array}$ & $\begin{array}{l}\text { Normal } \\
\text { Normal } \\
\text { Normal } \\
\text { Normal } \\
\text { Normal } \\
\text { Normal } \\
\text { Normal } \\
\text { Normal } \\
\text { Normal } \\
\text { Normal } \\
\text { Normal } \\
- \\
- \\
\text { Diabetic } \\
\text { Normal } \\
\text { Normal }\end{array}$ \\
\hline
\end{tabular}

Lipoprotein electrophoresis was performed in 12 cases on polyacrylamide gel, by the method of Pratt and Dangerfield (1969). In this method the very low density lipoproteins, corresponding to the prebetalipoprotein band in paper electrophoresis, do not migrate as far as the low density lipoproteins (betalipoprotein band) and are therefore found behind and not in front (postbeta and not prebeta). The characteristic pattern found in the present series is shown in Fig. 2, and this pattern occurred in all 12 patients investigated in this way.

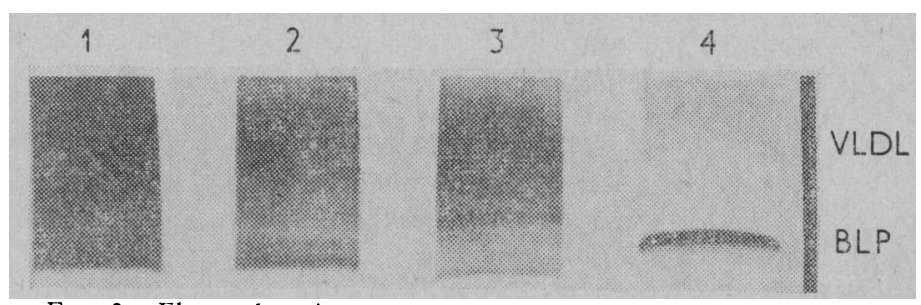

Fig. 2.-Elcctrophortic patterns. 1, Case 2. 2, Case 7. 3, Case 1. 4, Normal control. VLDL = very low density lipoprotein. BLP=betalipoprotein.

\section{Discussion}

The diagnosis in the present series has been based on the serum lipids, the cutaneous lesions, and lipoprotein pattern. The degree of triglyceridaemia together with the presence of tuberose xanthomata in all cases is probably sufficient to make a diagnosis of type III hyperlipoproteinaemia, as described by Fredrickson and Lees (1966). This is not invalidated by their later statement that a slight rise in triglycerides may be found in type II (Fredrickson et al., 1967). The electrophoretic patterns were all similar and showed a normal betalipoprotein 
band but a greatly increased very low density lipoprotein (prebetalipoprotein) band (Fig. 2). This might have been interpreted as a diagnosis of type IV were it not for the constant presence of tuberose xanthomata, which are said not to occur in type IV (Fredrickson and Lees, 1966). This bears out the opinion of Pries et al. (1968) that a firm diagnosis cannot be based on the lipoprotein pattern alone. Admittedly, these workers (Baes et al., 1968) maintain that tuberose xanthomata do occur in type IV, but their finding of nine type IV and only three type III cases in a series of 25 (the other 13 being type II) is highly suspect, type IV being generally considered to be much less common than type III. Matthews (1968) reported the occurrence of types III and IV in the same family, suggesting that these types may be different manifestations of the same condition. In any case these differing findings underline the difficulty in assigning cases to Fredrickson's various types, a difficulty which will be solved only by thorough investigation of larger groups of cases and by metabolic studies.

All types of xanthomata were found, and in particular the frequent involvement of the palmar aspect of the fingers and hands was noted (cf. Fredrickson et al., 1967). Eruptive xanthomata were present in five cases, but soon cleared as the serum triglycerides were reduced by treatment. On the other hand, only three patients had tendon xanthomata and one xanthelasma, lesions which Fredrickson et al. (1967) maintain are common in type III. Presenile arcus was also uncommon, and this is interesting in view of the fact that there is some evidence to suggest that presenile arcus may be associated with an increased incidence of myocardial infarction (Shanoff and Little, 1964).

The disease presented characteristically in adult life in all cases. The great preponderance of males over females (14 to 4), however, differs from the series of Fredrickson and Lees (1966), in which the sexes were equally affected. The four women in the present series are worthy of note because of the finding of cardiovascular disease in two of them.

All 18 patients in the present series presented in the first place with skin lesions. During the period of observation only eight other cases presented in this way, suggesting that type III hyperlipoproteinaemia is perhaps the commonest cause of cutaneous xanthomata associated with hyperlipidaemia.

It appears that the disease persists indefinitely. In all cases in which treatment has been discontinued the serum lipid levels have slowly risen over the months and the cutaneous lesions have begun to reappear after two to three years. In two of the present series (Cases 2 and 6 ) the condition has been present for 30 years and both are leading normal lives.

Probably the most striking finding in the present series is the extremely low incidence of coronary artery disease (Table II) among the male patients. Inspection of the Registrar General's reports suggests that it is probably no greater than twice the incidence expected over the same period of time among the general population. This becomes even more remarkable when considered in the light of the serum lipid levels and the duration of the disease. Fredrickson et al. (1967) found a high incidence of coronary artery disease in their type III cases, but there were equal numbers of men and women in their series. If, as appears from the present series, the incidence of cardiovascular disease in type III lipoproteinaemia is higher among women than among men, a higher proportion of female patients may present in the cardiac clinic. Thus if Fredrickson et al. (1967) obtained their patients through the cardiac clinic it would explain why their sex incidence was equal. In the present series none of the patients were referred from the cardiac clinic.

There was no increased incidence of death from ischaemic heart disease in first-degree relatives (Table III). Slack and
Nevin (1968), investigating first-degree relatives of 21 patients with hypercholesterolaemic xanthomatosis with hypertriglyceridaemia, made a similar finding.

Fredrickson et al. (1967) also commented or the incidence of peripheral occlusive vascular disease, stating that it was at least as frequent as coronary atherosclerosis, which they found in five out of eight cases (Frederickson and Lees, 1966). The occurrence of two cases of peripheral arterial block (Cases 1 and 12 ) in the present series of 18 patients probably also reflects an increased incidence of this type of vascular disease.

A raised serum uric acid level is common in both type II and type III hyperlipoproteinaemia. It has been suggested that, quite apart from this association, its presence may also be associated with coronary heart disease (Myers et al., 1968), but this was not so in the present series. Fredrickson et al. (1967) found carbohydrate intolerance present in over $90 \%$ of their cases, as shown by abnormal glucose tolerance tests (Fredrickson and Lees, 1966), but only one out of their total of 24 cases suffered from true diabetes.

Finally, the results of treatment were identical to those reported by Fredrickson et al. (1967) and Levy et al. (1967). The serum lipids could be very considerably reduced by a number of measures. Weight reduction was always effective in the obese, followed in all cases by a maintenance diet containing not more than $40 \%$ carbohydrate. Various cholesterolreducing substances have been used over the years, some of which have been reported on, such as polyunsaturated fats, norethandrolone (Borrie, 1964a), and Atromid (clofibrate) (Borrie, 1964b). The most striking effects of these treatments, however, have been on the skin lesions. Eruptive xanthomata cleared in every case in a few months. The lesions on the fingers and hands have completely resolved in every case, and the tuberose xanthomata have either cleared or been reduced in size by at least $50 \%$. The characteristic lipoprotein distribution seen on electrophoresis, however, remains undisturbed, even though the total lipid levels in the serum may return to near normal levels.

I should like to thank Dr. W. G. Dangerfield for the lipoprotein electrophoresis and permission to publish Fig. 2, Dr. John Hamer for the cardiovascular reports, Dr. Joan Slack for many of the serum lipid investigations and much helpful criticism and advice, Mr. Tredinnick and the staff of the department of medical illustration, St. Bartholomew's Hospital, for Fig. 1, and, last but not least, my long-suffering patients and house-physicians for respectively giving and taking countless specimens of blood.

\section{REFERENCES}

Baes, H., Polano, M. K., Pries, C., and Van Gent, C. M. (1968). Dermatologica, 136, 300.

Borrie, P. (1957). British Medical fournal, 2, 911.

Borrie, P. (1964a). Lancet, 1, 828.

Borrie, P. (1964b). British fournal of Dermatology, 76, 53.

Frederickson, D. S., and Lees, R. S. (1966). In The Metabolic Basis of Inherited Disease, edited by J. B. Stanbury, J. B. Wyngaarden, and
D. S. Fredrickson, 2nd ed., p. 429 . New York, McGraw-Hill.

Fredrickson, D. S., Levy, R. I., and Lees, R. S. (1967). New England fournal of Medicine, 276, 215.

Levy, R. I., Quarfordt, S. H., Sloan, H. R., Brown, W. V., and Fredrickson, D. S. (1967). Circulation, 36, Suppl. No. 2, p. 171. Matthews, R. J. (1968). American fournal of Medicine, 44, 188.

Myers, A. R., Epstein, F. H., Dodge, H. J., and Mikklesen, W. M. (1968). American fournal of Medicine, 45, 520.

Pratt, J. J., and Dangerfield, W. G. (1969). Clinica Chimica Acta, 23,

ries, C., Van Gent, C. M., Baes, H., Polano, M. K., Hulsman, H. A. M., and Querido, A. (1968). Clinica Chimica Acta, 19, 181.

Shanoff, H. M., and Little, J. A. (1964). Canadian Medical Association fournal, 91, 835.

Slack, J., and Nevin, N. C. (1968). J. Iurnal of Medical Genetics, 5, 4. 